\title{
The feeding behaviour of the water buffalo monitored by a semiautomatic feed intake recording system*
}

\author{
Barrio J.P. ${ }^{1}$, S.Y. Zhang ${ }^{2}$, Z.K. Zhu' ${ }^{2}$, F.L. Wu ${ }^{2}$, X.Z. $\mathrm{Mao}^{2}$, \\ F.F. Bermúdez ${ }^{3}$ and J.M. Forbes ${ }^{4}$ \\ ' Department of Physiology, University of León \\ 24071 León, Spain \\ ${ }^{2}$ College of Veterinary Medicine, Nanjing Agricultural University \\ 6 Tongwei Road, 210095 Nanjing, Jiangsu, China \\ ${ }^{3}$ CSIC Agricultural Experimental Station \\ Grulleros, León, Spain \\ ${ }^{4}$ Centre for Animal Sciences, Leeds Institute of Biotechnology and Agriculture, \\ University of Leeds \\ Leeds LS2 9JT, United Kingdom
}

(Received 17 May 1999; accepted 13 January 2000)

\begin{abstract}
Records were made on the feeding activity of eight water buffaloes (Bubalus bubalis) individually penned in the animal house at Nanjing Agricultural University during June-August 1996, fed ad libitum with Leymus chinensis hay. The weight of the feed container suspended from load cells was continuously monitored for 30 days through a portable computer reading data from a multiplexed serial analog-to-digital converter. Processed records provided a list of meals for each buffalo on each day. Meals taking place over many days for each animal at similar times of day were grouped into clusters by maximizing the distance between clusters and minimizing the distance within. Intake parameters analyzed in each cluster included number of meals, starting time, meal duration, meal weight, rate of eating, hunger ratio, and satiety ratio. All the individuals showed a strong stimulation of intake at the time when fresh hay was offered, taking a first meal which lasted an average of two hours at the highest intake rate of the day. Just before a night-time resting period a second big cluster was found. Satiety ratios were shown to increase as the day
\end{abstract}

* Supported by an European Union project, INCO-DC Programme, IC18-CT95-0001 (DG12-VLSA) 
proceeded, reaching a maximum in the evening. It is concluded that cluster analysis is a useful tool for summarising feeding behaviour and that the feeding behaviour of buffaloes is similar to that of cattle kept under similar conditions.

KEY WORDS: feeding behaviour, water buffalo, cluster analysis

\section{INTRODUCTION}

Feeding behaviour can be defined as the set of actions by which animals ingest the nutrients needed to satisfy their organic needs while avoiding non-alimentary or toxic substances (Gallouin and Focant, 1980). The search for and selection of the feed, as well as its uptake, mastication and deglutition are aspects within the scope of feeding behaviour which includes the set of meals taken by the animal and their time distribution.

Ruminants spend between about 3 and $12 \mathrm{~h}$ per day ingesting the amounts of feed they require (Dulphy and Faverdin, 1987). When grazing, a large proportion of the feed intake is found grouped into two large meals, one soon after dawn, the other before nightfall, with variable intermediate meals (Dulphy et al., 1980). In housed animals, feeding activity is mainly deternined by the distribution of fresh feed, which stimulates intake even when the previously offered feed has not been completely eaten (Dulphy and Faverdin, 1987). However, the bulk of feeding activities are distributed over the day so that summarizing feeding behaviour data over 24-h periods is a complex task. Bermúdez et al. (1989), tried to simplify the description of the feeding behaviour of sheep by dividing the day into 6 consecutive periods and presenting relevant parameters for each period.

The water buffalo (Bubalus bubalis) is a key animal in the farming activities of people living in warm and humid areas, mainly in Asia. In China there are about 2.2 million water buffaloes, farmed over eighteen provinces, especially in East and South China.

While it is recognized that voluntary feed intake is one of the major determinants of animal productivity, there is a lack of information in the literature on the feeding habits of the water buffalo. Water buffaloes are used for work in rice fields and also for meat and milk production. Reduction of voluntary feed intake is one of the first signs of many ruminant diseases, including infestation with helminths (Dargie, 1987; Ferre et al., 1994). Anorexia induced by Fasciola hepatica infection, as well as liver metabolism impairment, can reduce labour and production capacities, and the economic losses for Chinese farmers are estimated as several hundreds of thousands of dollars every year.

The aim of the present work was to establish an automatic feed intake recording system in order to get information on the feeding behaviour of indoor-stabled water buffalo fed ad libitum on grass hay which will form a useful foundation for 
further studies of the feeding behaviour in different conditions. The system is being used in the evaluation of effects of the experimental infection with Fasciola hepatica on feeding behaviour within the framework of the project "Water buffalo fasciolosis in China: seroepidemiological and pathophysiological studies and development of new diagnostic and therapeutical approaches", funded by the European Union. Preliminary information has been published elsewhere (Zhang et al., 1997).

\section{MATERIAL AND METHODS}

\section{Animals}

Eight castrated male water buffaloes, aged approximately 2-3 years and obtained from Luhe county of Jiangsu province (China), were kept in individual stalls ( $1 \mathrm{~m}$ wide) in an animal house from June to August 1996. The animals were fed on hay (Leymus chinensis) after 7-days preadaptation on rice straw. The composition of the hay was DM/kg $932 \mathrm{~g}$; per $\mathrm{kg} \mathrm{DM} \mathrm{g:} \mathrm{ash,} \mathrm{47.0;} \mathrm{crude} \mathrm{protein,} \mathrm{73.7;}$ crude fibre, 358.1 , and $\mathrm{N}$-free extractives 432.5 . Feed was offered daily at $15 \%$ more than that consumed in the previous day. Drinking water was available ad libitum from cement water containers shared between each two animals. Indoor daytime temperature was about $28^{\circ} \mathrm{C}\left(\max 34^{\circ} \mathrm{C}\right.$, $\left.\min 25^{\circ} \mathrm{C}\right)$ and ventilation was assisted by large overhead fans. The animals received individual showers twice a day by means of a series of pipes connected to a common tap. Between 8:00 - 9:00 animals werc out for exercise, the animal house was cleaned and fresh hay was offered for the whole day.

\section{Monitoring feeding behaviour}

A framework was arranged in order to allow for individual feed containers to be suspended and their weight measured. The dimensions of each container were $60 \times 100 \times 65 \mathrm{~cm}$, making it possible to hold more than $20 \mathrm{~kg}$ hay. Each one was made from thin galvanised steel sheet, with the bottom curved, weighing approximately $15 \mathrm{~kg}$.

\section{Sensors}

The principle of the feed intake data acquisition system is to measure continuously the weight of the feed containers, which will decrease as the animal consumes the hay inside. The procedure is an adaptation of previously used designs (Suzuki et al., 1968; Bermúdez et al., 1991). The weight was detected 
using strain gauge sensors, consisting of flat, thin-film resistors whose electrical resistance changes when stretched or compressed. These strain gauges (RS Amidata S.A., Madrid, Spain) were glued on a polished metal surface to build a load cell. In our case the load beams were aluminium arms from which the feed containers were suspended. Because of the dimensions and weight of each container, the empty or full container had to be shared using two aluminum arms $120 \times 20 \times 4 \mathrm{~mm}$, each fitted with one strain gauge (Figure 1a).

However, because of the animal activity the type of sensor had to be eventually changed, as described later in this section.

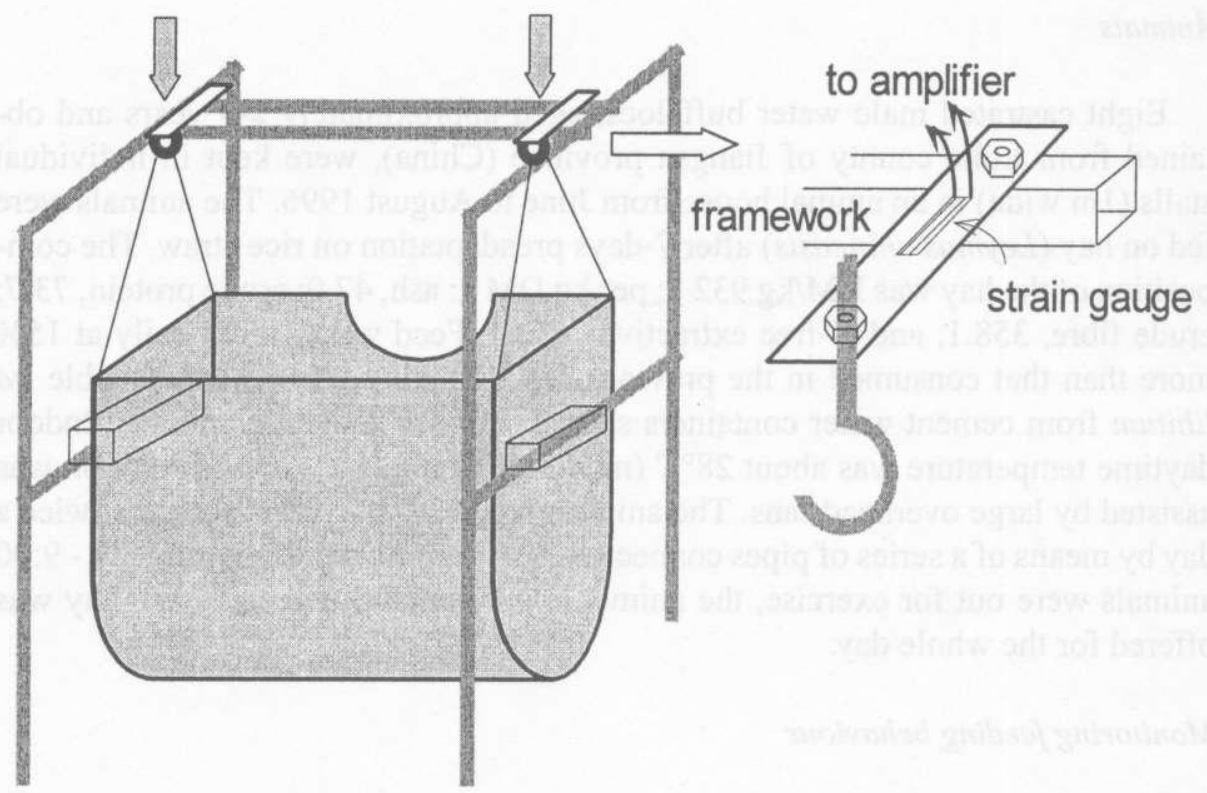

Figure 1a. Schematic arrangement of a water buffalo feed intake container including the strain gaugebased weight detector. A restraint on the second horizontal framework bar (not shown) prevented excessive bending of the load beam

\section{Amplifiers}

The change in the electrical resistance is linearly related to the degree of bending the load beams. Since the changes in the weight of the container are very small, they need to be properly amplified. To do that, the sensors are arranged to be a half Wheatstone bridge, and the other half of the bridge was completed using $120 \mathrm{ohm}$ resistors. In order to detect the overall resistance changes for both sen- 
sors, they had to be arranged in a reversed way, one strain gauge being glued on the top of the first aluminum arm, and the other glued on the bottom of the second one; otherwise the resistance changes when both aluminum arms are distorted would not be detected because of the mutually canceling effect. To minimize electrical noise, all wiring was made using multi-core screened wires. The variations in electrical resistance being translated into voltage changes are very small so that they must be amplified in order to reach practical voltage levels. We have used an amplifier (RS Amidata S.A., Madrid, Spain) specially designed to be used with strain gauge sensors, with variable gain of up to 1000 . The bridge voltage can also be adjusted using multi-turn variable resistors. Powered by a constant $5 \mathrm{~V}$ power supply, we set the final output voltage to $1.0 \mathrm{~V}$ with the bucket empty, and about $4 \mathrm{~V}$ with the feed container full.

\section{Analog-digital conversion unit}

The analogue signal that varies with the weight of the feed container has to be translated into digital values for input into a computer. An analogue-to-digital converter unit (Pico ADC-16) was purchased from RS Amidata S.A. (Madrid, Spain) with portability and ruggedness as major features. The unit is connected to a single serial port to the computer, from which it is also powered, and provides eight analog input channels. The analog data are translated into digital values, which are sent serially to the PC at 9600 bits per second. The resolution of the unit, i.e., the number of significant bits of the converted digital value, can be fixed from 8 to 16 , which gives an accuracy in the conversion process from 256 to 65536 steps, respectively. At its maximum accuracy, the unit achieves an average conversion speed (from the analog stage to the digital input read by the software) of one datum per second. The software was set to work at 14 bit resolution, giving 4096 steps or a theoretical sensitivity of nearly one millivolt (approximately 5 grams) according to our voltage output from the amplifiers.

\section{Problems with the original design}

It soon became apparent that the force exerted by the water buffalo when pushing the container to eat from the hay inside was excessive for the aluminium sensors; the effect of the horns on the suspending cables was also noticeable and it was decided that a major re-design was needed. Commercially available load cells were used (model L2330P, Futek advanced sensor technology Inc., Laguna Hills, California, USA) sturdy enough to measure a $40 \mathrm{~kg}$ load with overload protection, and a full-load sensitivity of $2 \mathrm{mV} / \mathrm{V}$. The wiring of the load cells was exchangeable with the previous sensors, and some minor adjustments were necessary to the electronics. Figure $1 b$ depicts the changes made to the contai- 
ners and framework to adapt this type of sensor. A single load cell was used on one side of the container, leaving the other hanging from two fixed points. This design was chosen because of the need of reduce the chances for damage by animal activity, especially horns, but a clear disadvantage is that the load needs to be evenly distributed in order to get accurate recordings. However, since the feed was always the same and there is no apparent reason for the buffaloes to ingest the hay unevenly, this fact was assumed not to be a source of problems and this was confirmed by observation.

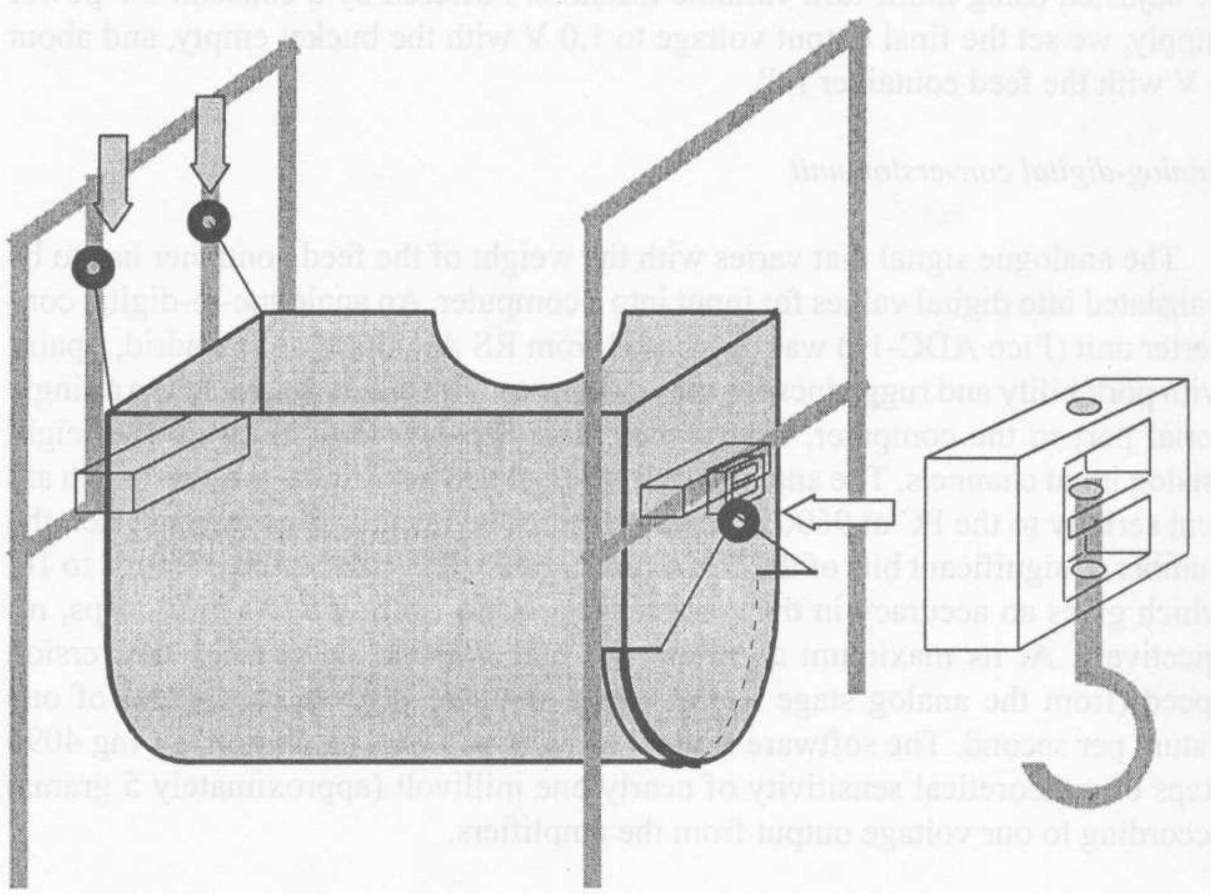

Figure 1b. Schematic arrangement of a water buffalo feed intake container as a result of the modifications made to the system. A metal arch with two soldered iron arms provided support to hang one side of the container from a load cell (on the right)

\section{Software}

A portable computer (IBM ThinkPad 340) was connected to the ADC unit through its serial port, allowing continuous monitoring of the incoming serial data. A special program (FIDAS, Feed Intake Data Acquisition System) was completed 
for receiving, analyzing and storing the data coming from the feed containers. The program received the digital data, analyzing the possible feed intake activity using a moving averaging technique to differentiate inactive periods from eating activities and storing the details of each meal. However, it was necessary to make visual verification (see below) as this part of the software was not completely reliable due to the considerable variations in the weight of each feed container from which any movement, such as the animal accidentally touching the feed container, can be interpreted as a feeding activity.

\section{Records}

The total weight of feed offered at 9:00 every day was recorded by using the above described automatic feed intake recording system. The computer was left recording the voltages corresponding to the weight of the empty containers for about one minute, and similarly after the containers were filled with hay, in order to set calibration marks to later assign the correct amounts to the meals detected. After that, the computer started recording just before the animals were returned to their stalls and given access to the containers.

The next day, raw data files were obtained in plain text (ASCII) format as a series of rows including: 1. identification tag of the animal starting acting on the container, 2. starting time of the feeding activity, 3. end time of such activity, 4 . starting voltage from the container, and 5 . final voltage detected when the activity ended. The data files were given a unique filename according to the actual date by the computer when the recording started.

\section{Feeding data processing}

The voltage values in the raw data files were translated into $\mathrm{kg}$ of hay after reading the initial calibrations. These secondary, translated files were next imported into a statistical package (Statistica, Statsoft, Tulsa OK, USA) in order to display the feeding pattern as weight vs time. Figure 2 is a sample of the recorded feeding activity for a given animal and day, by plotting the time and weight data pairs recorded by the system (after suitable volt-weight conversion). While the slope of the baseline indicates the amount of feed ingested (as the amount of feed in the container decreases), peaks show changes on the pressure applied by the animal on the container as it eats. The different meals were visually identified from the plots and their defining parameters (stall number, starting time and weight, final time and weight) stored in the corresponding results file according to their graphical coordinates. Blind checking of the meal identification process were made by three independent observers, accepting meals identified within a $5 \%$ variation. 


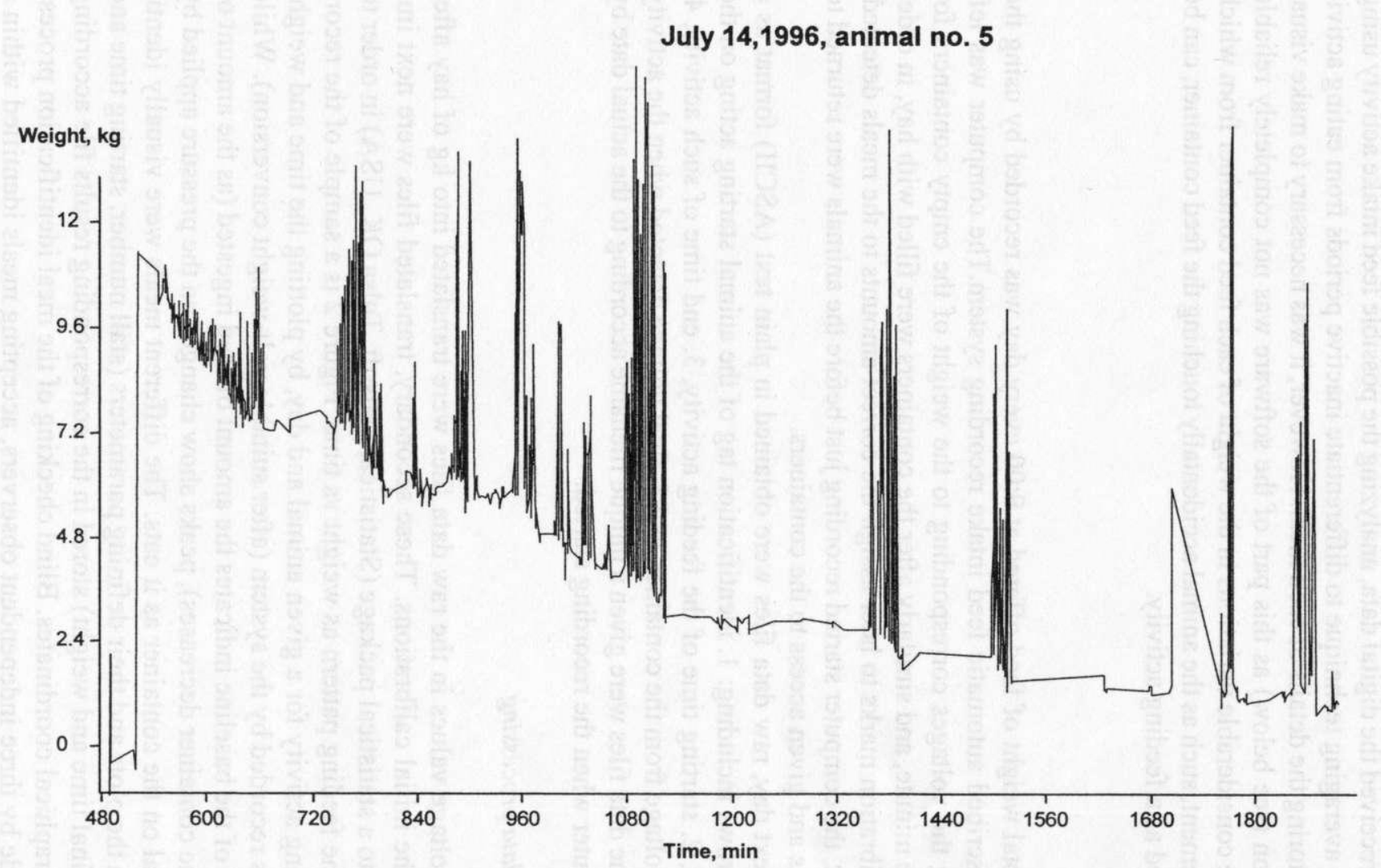

Figure 2. Sample pattern of buffalo feed intake for animal no. 5 on July 14, 1996. The figure shows a plot of weight vs time of the recorded changes in the hay container detected by the system as the animal was acting on the feed container while eating. Time is expressed in minutes since midnight 


\section{RESULTS}

\section{Overall feed intake}

Recording was performed daily from 25 June to 23 July 1996. During this period the body weight of the animals averaged $380.8 \pm 11.3 \mathrm{~kg}$, with a mean daily DM hay ingested of $8.33 \pm 0.28 \mathrm{~kg}$. Table 1 summarizes the results on total daily feed intake obtained by manually weighing the offered hay: body weight, amount of hay ingested daily, dry matter of hay ingested daily and dry matter of hay ingested relative to the metabolic weight of the animals.

TABLE 1

Daily feed intakes of water buffaloes during the experimental period

\begin{tabular}{ccccc}
\hline $\begin{array}{c}\text { Buffalo } \\
\text { no. }\end{array}$ & $\begin{array}{c}\text { Body weight } \\
\mathrm{kg}\end{array}$ & $\begin{array}{c}\text { Amount of hay } \\
\text { ingested } \mathrm{kg} / \mathrm{day}\end{array}$ & $\begin{array}{c}\text { DM hay ingested } \\
\mathrm{kg} / \mathrm{day}\end{array}$ & $\begin{array}{c}\mathrm{DM} / \mathrm{kg}\left(\mathrm{BW} \mathbf{W}^{0.75}\right) \\
\mathrm{g} / \mathrm{day}\end{array}$ \\
\hline 1 & 391.0 & $8.42 \pm 1.40$ & $7.31 \pm 1.22$ & 83.14 \\
2 & 414.0 & $10.53 \pm 1.17$ & $9.15 \pm 1.02$ & 99.69 \\
3 & 402.0 & $11.03 \pm 1.12$ & $9.58 \pm 0.97$ & 106.71 \\
4 & 339.7 & $9.22 \pm 0.98$ & $8.01 \pm 0.85$ & 101.23 \\
5 & 343.3 & $9.54 \pm 1.20$ & $8.29 \pm 1.04$ & 103.94 \\
6 & 378.0 & $9.55 \pm 1.12$ & $8.30 \pm 0.97$ & 96.82 \\
7 & 415.7 & $9.43 \pm 1.19$ & $8.19 \pm 1.03$ & 88.96 \\
8 & 362.7 & $9.01 \pm 1.49$ & $7.83 \pm 1.29$ & 94.21 \\
Mean \pm SEM & $380.8 \pm 11.3$ & $9.59 \pm 0.83$ & $8.33 \pm 0.28$ & $96.84 \pm 2.78$ \\
\hline
\end{tabular}

Feeding analysis

Feed intake parameters were extracted from the results file on a daily basis for each animal, numbered from 1 to 8 . The sensor for animal no. 6 failed to provide appropriate records during the monitoring period. The parameters included daily number of meals, total daily intake, and total eating time. One-way analysis of variance was performed using the above parameters as dependent variables and the animal identification number as independent variable, followed by post-hoc comparisons using the Duncan test (Table 2). Tables $3 \mathrm{a}$ to $3 \mathrm{~g}$ show the relevant feeding behaviour parameters extracted from the analysis of the daily meal patterns during 28 days by individual animals. Since it was apparent from the graphic plots that each animal had a preference to initiate meals at similar moments in successive days, a cluster technique was used to classify similar meals into discrete groups (clusters). This statistical procedure maximizes the distance between clusters and minimizes the distance between the mem- 
TABLE 2

Means, standard errors and $95 \%$ confidence intervals from the analysis of variance of daily intake time, daily number of meals, and daily total intake by animal identification number (ID). For each parameter, means with the same superscript number do not differ significantly $(\mathrm{P}>0.05$, Duncan test $)$

\begin{tabular}{|c|c|c|c|c|c|}
\hline \multirow{2}{*}{$\begin{array}{l}\text { Dependent } \\
\text { variable }\end{array}$} & \multirow[t]{2}{*}{ ID } & \multirow[t]{2}{*}{ Mcan } & \multirow[t]{2}{*}{ SE } & \multicolumn{2}{|c|}{$95 \%$ Confidence interval } \\
\hline & & & & lower bound & upper bound \\
\hline \multirow[t]{7}{*}{ Daily intake time } & 1 & $425.8^{25}$ & 17.18 & 391.5 & 460.0 \\
\hline & 2 & $345.4^{1457}$ & 19.59 & 306.4 & 384.4 \\
\hline & 3 & $410.8^{5}$ & 30.97 & 349.0 & 472.5 \\
\hline & 4 & $441.5^{25}$ & 17.18 & 407.2 & 475.7 \\
\hline & 5 & $487.8^{12.3478}$ & 15.02 & 457.9 & 517.8 \\
\hline & 7 & $427.6^{25}$ & 18.67 & 390.4 & 464.9 \\
\hline & 8 & $398.2^{5}$ & 18.67 & 361.0 & 435.4 \\
\hline \multirow[t]{7}{*}{ Daily no. of meals } & 1 & $8.1^{2}$ & 0.44 & 7.2 & 8.9 \\
\hline & 2 & $4.9^{1.34578}$ & 0.50 & 3.9 & 5.9 \\
\hline & 3 & $7.5^{2}$ & 0.79 & 5.9 & 9.1 \\
\hline & 4 & $6.9^{2}$ & 0.44 & 6.1 & 7.8 \\
\hline & 5 & $7.6^{2}$ & 0.38 & 6.9 & 8.4 \\
\hline & 7 & $6.8^{2}$ & 0.47 & 5.9 & 7.8 \\
\hline & 8 & $6.9^{2}$ & 0.47 & 6.0 & 7.9 \\
\hline \multirow[t]{7}{*}{ Daily total intake } & 1 & $8.9^{235}$ & 0.38 & 8.2 & 9.7 \\
\hline & 2 & $10.5^{14}$ & 0.43 & 9.7 & 11.4 \\
\hline & 3 & $11.9^{54578}$ & 0.68 & 10.5 & 13.2 \\
\hline & 4 & $9.3^{23}$ & 0.38 & 8.5 & 10.0 \\
\hline & 5 & $10.0^{13}$ & 0.33 & 9.3 & 10.7 \\
\hline & 7 & $9.5^{3}$ & 0.41 & 8.7 & 10.4 \\
\hline & 8 & $10.0^{3}$ & 0.41 & 9.2 & 10.8 \\
\hline
\end{tabular}

bers of each cluster (within-cluster). In this study the clustering was made through the K-means procedure (Statistica) with the center of the clusters estimated by maximizing the initial between-cluster distance. In this way, a number of meal clusters was obtained for each individual animal during the recording period, and the following standard feed intake parameters, as used by a number of authors (see Forbes, 1995) were characterized:

Starting time $(\mathrm{min})$. This represents the average starting point of the $\mathrm{n}$ meals constituting a given cluster. The figures are minutes since midnight, so that 8:00 am corresponds to $480 \mathrm{~min}$. The first meal made each day followed the filling of the feed container with fresh feed.

Meal duration $(\mathrm{min})$ and meal size $(\mathrm{kg})$ are the time elapsed eating a discrete meal and the amount of hay ingested, respectively. Figure 3 depicts the placement of the different clusters along the day for animal no. 1, showing the ave- 
TABLE 3a

Feeding behaviour parameters from the cluster analysis of fecd intake data during 15 non-consecutive days for water buffalo no. 1. Data are presented as mean (left column) \pm SEM (right column). $\mathrm{N}=$ number of meals included in each cluster. Intake is expressed as $\mathrm{kg}$ of fresh matter

\begin{tabular}{rccccccccccccc}
\hline N & $\begin{array}{c}\text { Starting time } \\
\text { min }\end{array}$ & \multicolumn{2}{c}{$\begin{array}{c}\text { Meal duration } \\
\text { min }\end{array}$} & \multicolumn{2}{c}{$\begin{array}{c}\text { Meal weight } \\
\mathrm{kg}\end{array}$} & $\begin{array}{c}\text { Rate of eating } \\
\mathrm{kg} / \mathrm{min}\end{array}$ & $\begin{array}{c}\text { Hunger ratio } \\
\mathrm{g} / \mathrm{min}\end{array}$ & $\begin{array}{c}\text { Satiety ratio } \\
\mathrm{min} / \mathrm{kg}\end{array}$ \\
\hline 15 & 530.40 & 4.56 & 127.87 & 18.30 & 3.48 & 0.55 & 0.037 & 0.009 & - & - & 13.62 & 2.56 \\
8 & 682.50 & 8.92 & 32.75 & 4.55 & 0.56 & 0.04 & 0.021 & 0.004 & 22 & 6 & 121.51 & 27.20 \\
14 & 774.71 & 6.37 & 43.64 & 5.15 & 0.77 & 0.08 & 0.020 & 0.002 & 30 & 6 & 60.57 & 13.88 \\
13 & 867.08 & 5.78 & 36.92 & 8.07 & 0.94 & 0.21 & 0.027 & 0.005 & 22 & 8 & 100.13 & 41.29 \\
15 & 948.20 & 6.77 & 43.47 & 8.20 & 0.72 & 0.18 & 0.017 & 0.004 & 21 & 4 & 150.65 & 50.86 \\
10 & 1067.30 & 6.55 & 32.70 & 5.80 & 0.77 & 0.20 & 0.022 & 0.003 & 13 & 1 & 696.35 & 454.9 \\
7 & 1158.43 & 10.68 & 35.29 & 3.25 & 0.60 & 0.24 & 0.016 & 0.005 & 07 & 1 & 1094.44 & 365.6 \\
3 & 1298.67 & 3.28 & 26.00 & 7.00 & 0.67 & 0.23 & 0.026 & 0.004 & 06 & 2 & 553.33 & 415.0 \\
1 & 1505.00 & - & 28.00 & - & 0.63 & - & 0.022 & - & 01 & - & 268.49 & - \\
9 & 1736.89 & 11.34 & 44.00 & 7.20 & 0.56 & 0.13 & 0.013 & 0.002 & 03 & 2 & 70.87 & 20.68 \\
7 & 1816.43 & 6.51 & 21.14 & 2.82 & 0.62 & 0.09 & 0.032 & 0.006 & 23 & 7 & 25.66 & 14.59 \\
3 & 1874.67 & 7.54 & 23.33 & 4.70 & 0.59 & 0.13 & 0.026 & 0.005 & 17 & 7 & - & - \\
\hline
\end{tabular}

TABLE $3 b$

Feeding behaviour parameters from the cluster analysis of feed intake data during 11 non-consecutive days for water buffalo no. 2. Data are presented as mean (left column) \pm SEM (right column). $\mathrm{N}=$ number of meals included in each cluster. Intake is expressed as $\mathrm{kg}$ of fresh matter

\begin{tabular}{rrrrrrrrrrrrrrrr}
\hline $\mathrm{N}$ & $\begin{array}{c}\text { Starting time } \\
\text { min }\end{array}$ & \multicolumn{2}{c}{$\begin{array}{c}\text { Meal duration } \\
\text { min }\end{array}$} & \multicolumn{2}{c}{$\begin{array}{c}\text { Meal weight } \\
\mathrm{kg}\end{array}$} & \multicolumn{2}{c}{$\begin{array}{c}\text { Rate of cating } \\
\mathrm{kg} / \mathrm{min}\end{array}$} & $\begin{array}{c}\text { Hunger ratio } \\
\mathrm{g} / \mathrm{min}\end{array}$ & $\begin{array}{c}\text { Satiety ratio } \\
\mathrm{min} / \mathrm{kg}\end{array}$ \\
\hline 11 & 524.18 & 4.35 & 133.45 & 14.59 & 5.71 & 0.66 & 47 & 5 & - & - & 17.97 & 3.75 \\
7 & 729.71 & 7.19 & 46.71 & 7.18 & 1.36 & 0.34 & 29 & 5 & 0.020 & 0.004 & 94.08 & 25.91 \\
11 & 857.00 & 10.01 & 50.36 & 9.36 & 1.19 & 0.31 & 27 & 4 & 0.014 & 0.002 & 124.43 & 45.47 \\
10 & 982.50 & 16.19 & 54.20 & 8.35 & 1.28 & 0.19 & 27 & 5 & 0.030 & 0.010 & 66.97 & 56.26 \\
4 & 1263.25 & 34.30 & 23.00 & 4.18 & 0.54 & 0.08 & 26 & 6 & 0.005 & 0.002 & 238.11 & 82.18 \\
3 & 1492.67 & 23.92 & 58.67 & 21.23 & 0.82 & 0.27 & 17 & 7 & 0.004 & 0.002 & 196.30 & 124.2 \\
3 & 1796.67 & 32.41 & 26.00 & 4.93 & 0.82 & 0.21 & 31 & 2 & 0.011 & 0.008 & - & - \\
\hline
\end{tabular}

rage meal weight and duration against the average starting time of the meals. Note that the first meal is by far the longest and heaviest, and the same can be observed in all individuals (Tables $3 \mathrm{a}-3 \mathrm{~g}$ ), a fact to be explained by the daily stimulus provided by the offering of new feed.

The ratio of weight:duration for each meal means the average Rate of eating $(\mathrm{kg} / \mathrm{min})$. Note that the figures for Rate of eating in Tables $3 \mathrm{a}-3 \mathrm{~g}$ are average values from individually calculated parameters for each meal included in a 
TABLE 3c

Feeding behaviour parameters from the cluster analysis of feed intake data during 4 non-consecutive days for water buffalo no. 3 . Data are presented as mean (left column) \pm SEM (right column). $\mathrm{N}=$ number of meals included in each cluster. Intake is expressed as $\mathrm{kg}$ of fresh matter

\begin{tabular}{crrrrrrrrrrrrr}
\hline$N$ & $\begin{array}{c}\text { Starting time } \\
\text { min }\end{array}$ & \multicolumn{2}{c}{$\begin{array}{c}\text { Meal duration } \\
\text { min }\end{array}$} & \multicolumn{2}{c}{$\begin{array}{c}\text { Meal weight } \\
\mathrm{kg}\end{array}$} & $\begin{array}{c}\text { Rate of eating } \\
\mathrm{kg} / \mathrm{min}\end{array}$ & $\begin{array}{c}\text { Hunger ratio } \\
\mathrm{g} / \mathrm{min}\end{array}$ & $\begin{array}{c}\text { Satiety ratio } \\
\mathrm{min} / \mathrm{kg}\end{array}$ \\
\hline 4 & 517.50 & 4.33 & 142.25 & 7.69 & 4.96 & 0.39 & 35 & 3 & - & - & 7.13 & 2.01 \\
4 & 694.00 & 11.10 & 46.50 & 11.81 & 1.46 & 0.47 & 28 & 5 & 0.056 & 0.028 & 222.99 & 172.6 \\
6 & 859.00 & 15.14 & 37.83 & 5.18 & 1.05 & 0.18 & 29 & 6 & 0.030 & 0.014 & 80.20 & 30.55 \\
3 & 968.67 & 12.81 & 23.00 & 13.61 & 0.59 & 0.26 & 41 & 6 & 0.016 & 0.005 & 125.21 & 61.00 \\
4 & 1077.50 & 11.46 & 61.75 & 14.98 & 1.58 & 0.50 & 28 & 7 & 0.015 & 0.004 & 265.96 & 118.3 \\
2 & 1249.00 & 45.00 & 32.00 & 13.00 & 1.20 & 0.59 & 36 & 4 & 0.009 & 0.001 & 337.48 & 225.2 \\
3 & 1524.00 & 31.63 & 31.67 & 8.11 & 0.85 & 0.49 & 25 & 9 & 0.004 & 0.003 & 188.85 & 137.4 \\
4 & 1772.75 & 12.32 & 23.25 & 5.34 & 0.62 & 0.12 & 31 & 11 & 0.008 & 0.005 & - & - \\
\hline
\end{tabular}

TABLE 3d Feeding behaviour parameters from the cluster analysis of feed intake data during 13 non-consecutive days for water buffalo no. 4. Data are presented as mean (left column) \pm SEM (right column). $\mathrm{N}=$ number of meals included in cach cluster. Intake is expressed as $\mathrm{kg}$ of fresh matter

\begin{tabular}{rrrrrrrrrrrrrrrr}
\hline $\mathrm{N}$ & $\begin{array}{c}\text { Starting time } \\
\mathrm{min}\end{array}$ & \multicolumn{2}{c}{$\begin{array}{c}\text { Meal duration } \\
\mathrm{min}\end{array}$} & \multicolumn{2}{c}{$\begin{array}{c}\text { Meal weight } \\
\mathrm{kg}\end{array}$} & $\begin{array}{c}\text { Rate of eating } \\
\mathrm{kg} / \mathrm{min}\end{array}$ & $\begin{array}{c}\text { Hunger ratio } \\
\mathrm{g} / \mathrm{min}\end{array}$ & $\begin{array}{c}\text { Satiety ratio } \\
\mathrm{min} / \mathrm{kg}\end{array}$ \\
\hline 13 & 518.77 & 2.96 & 149.00 & 8.91 & 4.15 & 0.22 & 28 & 1 & - & - & 23.33 & 3.17 \\
14 & 762.14 & 10.79 & 43.14 & 4.85 & 0.77 & 0.10 & 18 & 1 & 0.009 & 0.001 & 126.81 & 29.25 \\
15 & 871.93 & 8.40 & 38.67 & 3.77 & 0.80 & 0.11 & 24 & 4 & 0.021 & 0.005 & 74.22 & 20.80 \\
20 & 997.85 & 8.41 & 64.80 & 8.76 & 1.16 & 0.16 & 19 & 1 & 0.040 & 0.010 & 150.23 & 33.85 \\
7 & 1209.00 & 33.22 & 40.57 & 7.95 & 0.71 & 0.14 & 20 & 4 & 0.012 & 0.005 & 485.88 & 304.7 \\
6 & 1426.83 & 21.83 & 38.67 & 8.36 & 0.46 & 0.07 & 13 & 2 & 0.004 & 0.002 & 511.45 & 125.1 \\
4 & 1610.25 & 24.13 & 32.25 & 9.82 & 0.75 & 0.23 & 39 & 9 & 0.003 & 0.000 & 93.49 & 55.22 \\
6 & 1755.67 & 4.26 & 40.83 & 9.80 & 0.74 & 0.18 & 19 & 2 & 0.017 & 0.014 & 13.36 & 11.79 \\
5 & 1826.00 & 11.40 & 38.00 & 7.95 & 1.06 & 0.34 & 27 & 4 & 0.018 & 0.009 & - & - \\
\hline
\end{tabular}

given cluster, so that they do not equal the quotient [meal weight]/[meal duration] as could be assumed from Tables $3 \mathrm{a}-3 \mathrm{~g}$. Intra-meal rate of eating could not be measured by our system. There was a tendency towards a constant rate of eating, except for the first meal, in which rate of eating slowed towards the end of the meal.

The Hunger ratio $(\mathrm{kg} / \mathrm{min})$ is a measure of the urge to eat, calculated from the size of a meal divided by the time interval preceding it. This parameter is not applicable to the first meal of the day. Satiety ratio $(\mathrm{min} / \mathrm{kg})$ is given as the 
TABLE 3e

Feeding behaviour parameters from the cluster analysis of feed intake data during 17 non-consectitive days for water buffalo no. 5. Data are presented as mean (left column) \pm SEM (right column). $\mathrm{N}=$ number of meals included in each cluster. Intake is expressed as $\mathrm{kg}$ of fresh matter

\begin{tabular}{rrrrrrrrrrrrrrr}
\hline$N$ & $\begin{array}{c}\text { Starting time } \\
\min \end{array}$ & \multicolumn{2}{c}{$\begin{array}{c}\text { Meal duration } \\
\min \end{array}$} & \multicolumn{2}{c}{$\begin{array}{c}\text { Meal weight } \\
\mathrm{kg}\end{array}$} & $\begin{array}{c}\text { Ratc of eating } \\
\mathrm{kg} / \mathrm{min}\end{array}$ & $\begin{array}{c}\text { Hunger ratio } \\
\mathrm{g} / \mathrm{min}\end{array}$ & $\begin{array}{c}\text { Satiety ratio } \\
\mathrm{min} / \mathrm{kg}\end{array}$ \\
\hline 17 & 516.47 & 2.25 & 152.06 & 6.88 & 3.90 & 0.17 & 26 & 1 & - & - & 18.75 & 2.49 \\
13 & 716.62 & 9.74 & 65.23 & 9.50 & 1.16 & 0.13 & 20 & 2 & 0.026 & 0.003 & 61.38 & 20.60 \\
14 & 813.93 & 7.12 & 41.64 & 4.52 & 0.77 & 0.10 & 19 & 2 & 0.017 & 0.003 & 110.60 & 33.88 \\
18 & 910.22 & 7.13 & 45.89 & 5.63 & 1.01 & 0.13 & 24 & 2 & 0.023 & 0.004 & 69.21 & 13.07 \\
20 & 1007.50 & 7.01 & 56.00 & 8.53 & 1.12 & 0.15 & 21 & 2 & 0.033 & 0.004 & 57.87 & 14.27 \\
15 & 1119.60 & 10.53 & 44.13 & 3.81 & 0.89 & 0.15 & 19 & 2 & 0.024 & 0.006 & 325.03 & 89.50 \\
9 & 1297.67 & 17.14 & 37.56 & 6.03 & 0.79 & 0.17 & 20 & 2 & 0.007 & 0.001 & 418.10 & 157.7 \\
6 & 1476.83 & 8.76 & 26.50 & 2.72 & 0.40 & 0.06 & 16 & 3 & 0.004 & 0.002 & 584.87 & 145.4 \\
5 & 1532.80 & 8.28 & 40.40 & 6.21 & 0.62 & 0.12 & 15 & 1 & 0.002 & 0.000 & 133.17 & 57.97 \\
10 & 1749.50 & 5.96 & 49.50 & 7.67 & 0.85 & 0.11 & 19 & 2 & 0.005 & 0.001 & 18.17 & 12.66 \\
3 & 1849.33 & 16.29 & 42.33 & 2.67 & 0.90 & 0.10 & 21 & 3 & 0.007 & 0.005 & - & - \\
\hline
\end{tabular}

TABLE $3 \mathrm{f}$ Feeding bchaviour parameters from the cluster analysis of feed intake data during 11 non-consecutive days for water buffalo no. 7. Data are presented as mean (left column) \pm SEM (right column). $\mathrm{N}=$ number of meals included in each ciuster. Intake is expressed as $\mathrm{kg}$ of fresh matter

\begin{tabular}{rrrrrrrrrrrrrr}
\hline$N$ & $\begin{array}{c}\text { Starting time } \\
\text { min }\end{array}$ & \multicolumn{2}{c}{$\begin{array}{c}\text { Meal duration } \\
\text { min }\end{array}$} & \multicolumn{2}{c}{$\begin{array}{c}\text { Meal weight } \\
\mathrm{kg}\end{array}$} & \multicolumn{2}{c}{$\begin{array}{c}\text { Rate of eating } \\
\mathrm{kg} / \mathrm{min}\end{array}$} & $\begin{array}{c}\text { Hunger ratio } \\
\mathrm{g} / \mathrm{min}\end{array}$ & $\begin{array}{c}\text { Saticty ratio } \\
\mathrm{min} / \mathrm{kg}\end{array}$ \\
\hline 11 & 523.45 & 2.96 & 108.91 & 9.33 & 2.44 & 0.22 & 22 & $!$ & - & - & 39.57 & 6.44 \\
11 & 705.45 & 14.47 & 41.36 & 5.99 & 1.47 & 0.25 & 37 & 3 & 0.027 & 0.006 & 73.45 & 16.88 \\
11 & 840.36 & 9.84 & 68.45 & 8.37 & 1.67 & 0.24 & 24 & 3 & 0.027 & 0.010 & 101.51 & 48.70 \\
13 & 977.62 & 12.75 & 52.15 & 11.65 & 1.42 & 0.24 & 19 & 5 & 0.033 & 0.007 & 202.17 & 71.68 \\
7 & 1184.29 & 21.99 & 47.29 & 12.89 & 0.81 & 0.23 & 21 & 5 & 0.012 & 0.006 & 513.51 & 135.9 \\
8 & 1412.50 & 18.42 & 54.13 & 12.27 & 0.74 & 0.13 & 15 & 3 & 0.003 & 0.001 & 1574.63 & 1210. \\
10 & 1750.90 & 8.18 & 48.30 & 11.17 & 0.94 & 0.14 & 23 & 3 & 0.005 & 0.002 & 38.73 & 24.44 \\
4 & 1833.00 & 18.34 & 33.50 & 6.85 & 1.06 & 0.24 & 31 & 2 & 0.014 & 0.009 & - & - \\
\hline
\end{tabular}

quotient between the time interval following a meal and the weight of the meal. It is not applicable to the last meal of the day, since the interval preceding the first meal of the day includes the exercising time of the animals and also the starting time for the first meal is conditioned by the replacement of each container's contents with fresh feed (see below). It is noteworthy that the hunger ratio decreased during the day, at the time when the satiety ratio was increasing. 
TABLE $3 g$

Feeding behaviour parameters from the cluster analysis of feed intake data during 11 non-conseculive days for water buffalo no. 8. Data are presented as mean (left column) \pm SEM (right column). $\mathrm{N}=$ number of meals included in each cluster. Intake is expressed as $\mathrm{kg}$ of fresh matter

\begin{tabular}{rrrrrrrrrrrrrrr}
\hline $\mathrm{N}$ & $\begin{array}{c}\text { Starting time } \\
\mathrm{min}\end{array}$ & \multicolumn{2}{c}{$\begin{array}{c}\text { Meal duration } \\
\mathrm{min}\end{array}$} & \multicolumn{2}{c}{$\begin{array}{c}\text { Meal weight } \\
\mathrm{kg}\end{array}$} & $\begin{array}{c}\text { Rate of eating } \\
\mathrm{kg} / \mathrm{min}\end{array}$ & $\begin{array}{c}\text { Hunger ratio } \\
\mathrm{g} / \mathrm{min}\end{array}$ & $\begin{array}{c}\text { Satiety ratio } \\
\mathrm{min} / \mathrm{kg}\end{array}$ \\
\hline 11 & 527.09 & 3.76 & 106.55 & 9.86 & 3.66 & 0.46 & 34 & 1 & - & - & 34.84 & 6.73 \\
13 & 750.69 & 11.72 & 51.69 & 7.61 & 1.01 & 0.14 & 22 & 2 & 0.013 & 0.003 & 101.54 & 28.51 \\
12 & 891.42 & 11.13 & 53.25 & 7.02 & 1.33 & 0.17 & 26 & 2 & 0.021 & 0.003 & 47.83 & 7.97 \\
13 & 1011.62 & 9.26 & 52.31 & 4.37 & 1.47 & 0.15 & 29 & 2 & 0.041 & 0.010 & 139.31 & 53.90 \\
6 & 1139.83 & 12.30 & 32.17 & 6.68 & 0.72 & 0.12 & 25 & 4 & 0.008 & 0.001 & 373.20 & 126.8 \\
3 & 1286.33 & 27.09 & 29.67 & 10.67 & 0.49 & 0.09 & 19 & 3 & 0.004 & 0.000 & 670.12 & 392.3 \\
4 & 1424.00 & 10.93 & 61.00 & 5.45 & 1.38 & 0.17 & 24 & 4 & 0.013 & 0.008 & 148.65 & 54.44 \\
2 & 1645.00 & 20.00 & 28.50 & 17.50 & 0.56 & 0.32 & 21 & 2 & 0.001 & 0.001 & 327.28 & 199.5 \\
12 & 1799.42 & 12.90 & 31.08 & 4.77 & 0.74 & 0.09 & 26 & 3 & 0.008 & 0.003 & - & - \\
\hline
\end{tabular}

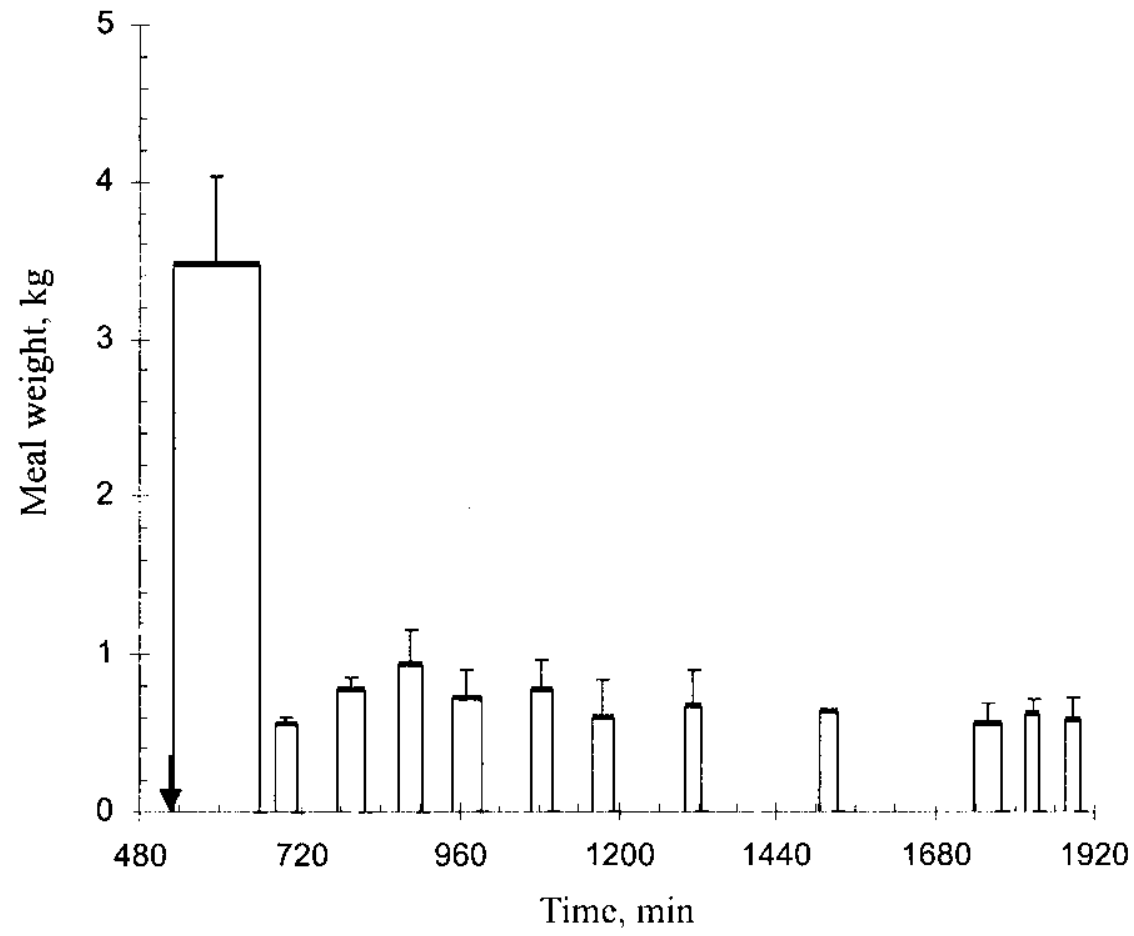

Figure 3. Average meal weight in each cluster ( $+\mathrm{SE}$ ) vs starting time for water buffalo no. 1. Time is expressed in minutes since midnight. The bar widht expresses the average duration of the meals included in the corresponding cluster. The arrow indicates the time fresh feed was offered 


\section{DISCUSSION}

The feeding behaviour of each water buffalo at the animal house at Nanjing Agricultural University, fed with grass hay and water ad libitum, was fairly constant day by day, as can be seen from the standard errors of the meal clusters found. However, Table 2 shows large and consistent differences between animals considering daily intake parameters such as number of meals, total daily intake and total time eating, and for this reason no attempt was made at this stage to get averages for the feed intake parameters for all the animals together. Such large differences between individuals in feed intake parameters have been noticed previously. Suzuki et al. (1968), for example, reported high variability in the rate of eating of silages between cows and Tolkamp et al. (1998) have emphasised the difficulty of understanding how voluntary intake is controlled when there are such large differences in meal patterns between animals, even when they eat similar amounts of feed each day.

One of the problems in studying feeding behaviour is the large amount of data collected and the difficulty of expressing this in a few parameters. We think cluster analysis improves the characterization of feeding behaviour since it can condense the feeding activities of a single animal along several days while still allowing for comparisons between animals. It is more satisfactory than dividing the day into periods (e.g. 6 per day; Forbes, 1995) and presenting the mean values of meal parameters for each period of the day.

All the individuals showed a strong stimulation of intake at the time when fresh hay was offered, taking a first meal which lasted an average of $2 \mathrm{~h}$. This stimulation is well known to appear in housed ruminants (Dulphy and Faverdin, 1987), but it is also possible that the exercising period before offering fresh feed contributed to enhance this response. However, Pearson and Smith (1994) found no difference between resting and exercised animals in terms of feed intake during $20 \mathrm{~h}$, with buffaloes spending less time eating and more ruminating than cattle; the animals were either prevented of eating for $4 \mathrm{~h}$ or exercised (walking) for the same time, and these treatments were compared against ad libitum feeding, when the intake was slightly higher. Since our animals were exercised for $1 \mathrm{~h}$ and then fed ad libitum, even smaller deviations from true ad libitum behaviour can be expected.

The rate of eating was also the highest in most of the animals for this first cluster of meals. The large meal frequently observed after dawn in other studies was not apparent here as the buffaloes were waiting for the delivery of fresh feed rather than eat a lot of that which had been in front of them for almost $24 \mathrm{~h}$.

A big cluster including the maximum number of meals was found from min 948 to 1065 from midnight, including generally the second biggest meal of the day, just before a night-time resting period of variable extent which included 
fewer and smaller meals than during the daytime. Satiety ratios show a distinct trend in each animal to increase as the day proceeds, reaching a maximum in the evening (between 1158 and $1477 \mathrm{~min}$ from midnight, see Table 2), and hunger ratios are correspondingly decreased. These results are consistent with the idea of a progressive increase in the level of feedback signals for the control of feed intake along the day, presumably from ruminal tension and epithelial receptors (Forbes and Barrio, 1992). It should be noted, however, that in cattle there is faster rate of passage and lower volume of rumen contents at night than in the day (Thiago et al., 1992) so that a simple physical explanation for the reduction in hunger ratio is not sufficient.

It is interesting to note the fact that meals, except the first, were not well synchronized between animals, even though they were eating in close proximity to each other. Adult cattle increase their feed intake when fed in groups, whenever enough space is provided (Forbes, 1995), but this does not necessarily mean meal synchronization: Dürst et al. (1993) found different feeding behaviour of three lactating cattle breeds after an initial, synchronized feed intake stimulation due to offering of feed, in the same way as we found in the water buffalo. These authors reported differences in number of meals, meal size and duration, eating rate, and daily total feed intake and intake time for all three breeds studied (Holstein-Friesian, Simmental and Jersey). It is noteworthy that the authors found correlations between meal size and intermeal intervals for some, but not all the animals, as indicative of the existence of individual preferences for feeding.

These results support the use of cluster analysis for the description of meal pattern as a useful tool to help to quantify the feeding behaviour in different experimental situations and/or natural environmental changes such as parasitic infection. It is a logical extension of the observation that the feeding pattern is circadian, synchronized in this case more by the time of offering fresh feed than by dawn.

Recently some other approaches to discuss feeding behaviour have appeared. Tolkamp et al. (1999) describe the presence of two different normally distributed populations of intervals between feeding activities, associated with short intervals within meals and longer intervals between meals. Our data were processed to describe the observed meals, without attempting to analyze short intervals. The possibilities of describing feeding behaviour by using different computational techniques such as cluster analysis and non-linear fitting methods are still being uncovered. 


\section{REFERENCES}

Bermúdez F.F.. Forbes J.M.. Jones R., 1989. Feed intakes and meal patterns of sheep during pregnancy and lactation, and after weaning. Appetite 13, 211-222

Bermúdez F.F., Barrio J.P., Amor J.J., Mantecón AR., 1991. Effect of the body condition and roughage type on the daily intake pattern of sheep (in Spanish). ITEA 11(1), 229-231

Dargie J.M., 1987. Trematode infections in sheep and cattle: effects on productivity and metabolism. In: W.H.D. Leaning, J. Guerrero (Editors). The Economic Impact of Parasitism in Cattle. Proceedings of the MSD AGVET Symposium, XXIII World Veterinary Congress. Montreal (Canada), pp. 35-43

Dulphy J.P., Faverdin P., 1987. L'ingestion alimentaire chez les ruminants: modalités et phénomènes associés. Reprod. Nutr. Dévelop. 27, 129-155

Dulphy J.P., Rémond B., Theriez M., 1980. Ingestive behaviour and related activities in ruminants. In: Y. Ruckebusch, P. Thivend (Editors). Digestive Physiology and Metabolism in Ruminants. MTP Press. Lancaster (UK), pp. 103-122

Dürst B., Senn M., Langhans W., 1993. Eating patterns of lactating dairy cows of three different breeds fed grass ad lib. Physiol. Behav. 54, 625-631

Ferre I., Barrio J.P., Gonzalez-Gallego J., Rojo-Vazquez F.A., 1994. Appetite depression in sheep experimentally infected with Fasciola hepatica L. Vet. Parasitol. 55, 71-79

Forbes J.M., 1995. Voluntary Feed Intake and Diet Selection in Farm Animals. CAB International, Wallingford (UK), pp.11-34

Forbes J.M., Barrio J.P., 1992. Abdominal chemo- and mechanosensitivity in ruminants and its role in the control of feed intake. Exp. Physiol. 77, 27-50

Gallouin F., Focant M., 1980. Bases physiologiques du comportament alimentaire chez le ruminant. Reprod. Nutr. Dévelop. 20, 1563-1614

Pearson R.A., Smith D.G., 1994. The effects of work on feed intake and ingestive behaviour of draught cattle and buffalo given barley straw. Anim. Prod. 58, 339-346

Suzuki S., Fujita H., Shinde Y., 1968. Change in the rate of eating during a meal and the effect of the interval between meals on the rate at wich cows eat roughages. Anim. Prod. 11, 29-41

Thiago L.R.L., Gill M., Sissons J.W., 1992. Studies of method of conserving grass herbage and frequency of feeding in cattle. 2. Eating behaviour, rumen motility and rumen fill. Brit. J. Nutr. $67,319-336$

Tolkamp B.J., Day J.E.L., Kyriazakis I., 1998. Measuring feed intake in farm and laboratory animals. Proc. Nutr. Soc. 57, 313-319

Tolkamp B.J., Kyriazakis 1., 1999. To split behaviour into bouts: log-transform the intervals. Anim. Behav. 57, 807-817

Zhang S.Y., Zhu Z.K., Wu F.L., Mao X.Z., Bermúdez F.F., González-Gallego J, Barrio J.P., 1997. Feed intake data acquisition system for the water buffalo (Bubalus bubalis). J. Physiol. Biochem. 53,74 


\section{STRESZCZENIE}

\section{Nawyki pobierania paszy przez indyjskie bawoly domowe monitorowane przez pólautoma- tyczny system pobierania paszy}

Nawyki pobierania paszy przez 8 indyjskich bawołów domowch (Bubalus bubalis) umieszczonych w indywidualnych kojcach w Uniwersytecie Rolniczym w Nanjing były rejestrowane dla każdego zwierzęcia przy żywieniu do woli sianem Leymus chinensis od czerwca do sicrpnia 1996. Ilość pobieranej paszy rejestrowano przez 30 dni stosując komputerowy system zapisu i po opracowaniu danych otrzymywano rejestr pobierania paszy w ciągu każdego đnia przez każde zwierzę. Pobieranie paszy przez każde zwicrze o tej samej porze przcz wiele dni zostało połączone w grupy na podstawie maksymalizacji odstępu pomiędzy pobraniami i minimalizacji odstępu wewnętrznego. W poszczególnych pogrupowanych zbiorach analizowano takie parametry pobierania paszy jak: częstotliwość pobierania, czas rozpoczęcia, czas trwania pobierania, ilość pobranej paszy, tempo jedzenia, współczynnik głodu, współczynnik sytości. U wszystkich zwierząt stwierdzono silną stymulację pobierania paszy w momencie oferowania świeżej jej partii. Przy pierwszym odpasie, trwającym średnio 2 godziny, tempo pobierania paszy było największe z całego dnia. Drugi okres intensywnego pobierania paszy stwierdzono tuż przed nocnym spoczynkiem. Współczynniki sytości wzrastały w ciągu dnia, osiągając maksymalne wartości wieczorem. W wyniku badań wnioskuje się, że analiza okresów pobierania paszy jest użytecznym narzędziem podsumowującym nawyki pobicrania paszy oraz, że te nawyki u bawołów są podobne jak u bydła utrzymywanego w podobnych warunkach. 